\title{
Identification, Phylogenetic Analysis, and Biological Characterization of Serratia marcescens Strains Causing Cucurbit Yellow Vine Disease
}

\author{
J. Rascoe, M. Berg, U. Melcher, F. L. Mitchell, B. D. Bruton, S. D. Pair, and J. Fletcher
}

First, second, and seventh authors: Department of Entomology and Plant Pathology; and third author: Department of Biochemistry and Molecular Biology, Oklahoma State University, Stillwater 74078; fourth author: Department of Entomology, Texas A\&M University, Stephenville 76401; and fifth and sixth authors: U.S. Department of Agriculture-Agricultural Research Service, Lane, OK 74555. Current address of J. Rascoe: Molecular Diagnostics, Agdia, Inc., 30380 CR 6, Elkhart, IN 46514. Current address of M. Berg: Department of Botany and Microbiology, Oklahoma State University, Stillwater 74078. Accepted for publication 23 April 2003.

\begin{abstract}
Rascoe, J., Berg, M., Melcher, U., Mitchell, F. L., Bruton, B. D., Pair, S. D., and Fletcher, J. 2003. Identification, phylogenetic analysis, and biological characterization of Serratia marcescens strains causing cucurbit yellow vine disease. Phytopathology 93:1233-1239.

A serious vine decline of cucurbits known as cucurbit yellow vine disease (CYVD) is caused by rod-shaped bacteria that colonize the phloem elements. Sequence analysis of a CYVD-specific polymerase chain reaction (PCR)-amplified $16 \mathrm{~S}$ rDNA product showed the microbe to be a $\gamma$-proteobacterium related to the genus Serratia. To identify and characterize the bacteria, one strain each from watermelon and zucchini and several noncucurbit-derived reference strains were subjected to sequence analysis and biological function assays. Taxonomic and phylogenetic placement was investigated by analysis of the $g r o E$ and $16 \mathrm{~S}$ rDNA regions, which were amplified by PCR and directly sequenced. For comparison, eight other bacterial strains identified by others as Serratia
\end{abstract}

ABSTRACT spp. also were sequenced. These sequences clearly identified the CYVD strains as Serratia marcescens. However, evaluation of metabolic and biochemical features revealed that cucurbit-derived strains of $S$. marcescens differ substantially from strains of the same species isolated from other environmental niches. Cucurbit strains formed a distinct cluster, separate from other strains, when their fatty acid methyl ester profiles were analyzed. In substrate utilization assays (BIOLOG, Vitek, and API 20E), the CYVD strains lacked a number of metabolic functions characteristic for $S$. marcescens, failing to catabolize 25 to 30 compounds that were utilized by $S$. marcescens reference strains. These biological differences may reflect gene loss or repression that occurred as the bacterium adapted to life as an intracellular parasite and plant pathogen.

Additional keywords: cantaloupe, Enterobacteriaceae, niche-adaptation, opportunistic pathogen, phloem-resident bacterium, squash, watermelon, zucchini.
Cucurbit yellow vine disease (CYVD) first was observed in Oklahoma in 1988 in pumpkin and squash $(8,10)$. Exhibiting characteristic symptoms of yellowing foliage, wilting, and phloem discoloration, this disease has since caused severe losses also in cantaloupe and watermelon crops. Disease incidence has varied annually from small, isolated outbreaks to complete crop loss, especially in early-planted fields (8). Originally thought confined to Oklahoma and central Texas, CYVD has since been confirmed in Arkansas (J. C. Correll, personal communication), Tennessee (6), Massachusetts (43), Kansas (N. A. Tisserat, J. Fletcher, and B. D. Bruton, unpublished data), Colorado (B. D. Bruton, unpublished data), and Nebraska (R. M. Harveson and B. D. Bruton, unpublished data).

Disease symptoms consistently are associated with the presence of rod-shaped bacteria in phloem sieve elements, detected using transmission electron microscopy (8). Avila et al. (3) amplified a nearly full-length $16 \mathrm{~S}$ rDNA fragment from infected tissue. The nucleotide sequence of this fragment suggested that the organism was a member of the $\gamma-3$ proteobacteria, with the nearest apparent relative being in the genus Serratia. From that sequence, Avila et al. (3) designed CYVD-targeted 16S rDNA primers, and Melcher et al. (27) later developed additional primers with greater specificity for CYVD, for use in polymerase chain reaction (PCR). PCR screening of CYVD-infected and healthy cucurbit plants established a consistent association between the amplification of the

Corresponding author: J. Fletcher; E-mail address: jaf2394@okstate.edu.

Publication no. P-2003-0725-01R

(C) 2003 The American Phytopathological Society specific PCR products and CYVD symptoms. The bacterium was isolated from diseased plant phloem and cultivated on artificial medium, and completion of Koch's postulates demonstrated that this microbe was indeed the etiological agent of CYVD (7-9). Furthermore, transmission of the CYVD bacterium from plant to plant was accomplished both mechanically, by needle inoculation of seedling cotyledons, and via the squash bug, Anasa tristis, a cucurbit insect pest not previously known to transmit any plant pathogen $(4,5,7,9)$.

The goals of this work were to identify and partially characterize the CYVD causal bacterium. Two CYVD strains and selected reference strains were evaluated phylogenetically by nucleotide sequencing of the $16 \mathrm{~S}$ rDNA and groE regions of the chromosome. Analysis of 16S rDNA sequences is one of the most useful and widely accepted means for assessment of the natural and taxonomic relationships of microorganisms $(18,19,42)$. However, because this gene is so highly conserved among species of the family Enterobacteriaceae, of which the genus Serratia is a member, attempts by others to construct molecular phylogenetic trees for this bacterial family based on 16S rDNA have been of limited success. Analyses of groE sequences, however, have been useful in the classification of closely related bacterial species, especially those in the family Enterobacteriaceae whose $16 \mathrm{~S}$ rDNA sequences are too highly conserved to be effective for distinction (16). The groE operon, encoding the chaperonin stress proteins GroES and GroEL, is highly conserved in the bacterial world and is essential for viability $(20,28)$. The CYVD and reference bacterial strains also were characterized biologically, using fatty acid profiling and substrate utilization tests (BIOLOG, Vitek, and API 20E). 
Our results show that the CYVD bacterium is, indeed, a member of the genus Serratia, and, in fact, that it is Serratia marcescens. Further, they demonstrate that the CYVD strains differ significantly in their biological functions and characteristics from other selected noncucurbit strains, which had been isolated from soil, plant interiors (nonpathogenic associations), and humans. A preliminary abstract has been published (30).

\section{MATERIALS AND METHODS}

Bacterial strains, growth conditions, and preliminary characterization. Two CYVD-derived bacterial strains, W01-A (watermelon) and Z01-A (zucchini), initially were cultivated on purple agar (Sigma-Aldrich, St. Louis) from phloem tissue excised from the crowns of infected plants, triply cloned to assure homogeneity, and maintained in frozen aliquots in 50\% glycerol at $-80^{\circ} \mathrm{C}$ as described $(7,9)$. Their identity was confirmed by the production of an amplicon of expected size using CYVD-specific primers in PCR (27) and by sequencing of the PCR product (Table 1). The type strain of $S$. marcescens (ATCC no. RF4738) and eight additional Serratia strains, originating from noncucurbit niches, were obtained from other investigators (Table 1). Bacteria were grown in Luria-Bertani (LB) broth (31) for 8 to $12 \mathrm{~h}$ with shaking at $28^{\circ} \mathrm{C}$. Gram status of the cell walls was determined by the $\mathrm{KOH}$ test, and the ability to grow under anaerobic conditions was tested using Hugh and Leifson's medium (O-F) sealed with Vaseline; both of these experiments were done as described by Schaad (32).

DNA isolation. DNA was extracted using a modified version of the hexadecyl trimethyl ammonium bromide (CTAB) method (2). Briefly, $3 \mathrm{ml}$ of log-phase cells were centrifuged for $5 \mathrm{~min}$ at $10,000 \times g$ and $4^{\circ} \mathrm{C}$, supernatant was removed, and cells were resuspended in $200 \mu \mathrm{l}$ of TE $(10 \mathrm{mM}$ Tris- $\mathrm{HCl}, 1 \mathrm{mM}$ EDTA, $\mathrm{pH}$ 8.0). The mixture was incubated for $30 \mathrm{~min}$ at $60^{\circ} \mathrm{C}$; then, $100 \mu \mathrm{l}$ of $5 \mathrm{M} \mathrm{NaCl}$ and $80 \mu \mathrm{l}$ of CTAB solution $(10 \% \mathrm{CTAB}$ in $0.7 \mathrm{M}$
$\mathrm{NaCl})$ were added and mixed, and the suspension was incubated at $60^{\circ} \mathrm{C}$ for $10 \mathrm{~min}$. The solution was extracted with an equal volume of phenol/chloroform/isoamyl alcohol (25:24:1), followed by DNA-precipitation and a wash with isopropanol and $70 \%$ ethanol, respectively.

PCR. Amplification and sequencing of the $g r o E$ region of the genome was performed with three primer sets: A1/B1, A2/B2, and A3/B3, as described by Harada and Ishikawa (18). Each reaction included $30 \mathrm{ng}$ of template DNA in a volume of $25 \mu \mathrm{l}$ containing $3.5 \mathrm{mM} \mathrm{MgCl} 2,0.05 \mathrm{mM}$ each dCTP, dATP, dTTP, and dGTP, $200 \mathrm{pM}$ of each primer (A1/B1, A2/B2, and A3/B3), and 1.5 units of $\mathrm{Taq}$ polymerase (Promega Corp., Madison, WI). The DNA was amplified under the following conditions: $3 \mathrm{~min}$ at $95^{\circ} \mathrm{C} ; 35$ cycles of $30 \mathrm{~s}$ at $94^{\circ} \mathrm{C}, 60 \mathrm{~s}$ at $55^{\circ} \mathrm{C}$, and $60 \mathrm{~s}$ at $70^{\circ} \mathrm{C}$; and final elongation at $72^{\circ} \mathrm{C}$ for $10 \mathrm{~min}$.

Amplification and sequencing of $16 \mathrm{~S}$ rDNA was achieved using universal primers fD1 and rP2 (21) and primers $\alpha\left(5^{\prime}\right.$-CTGCTGCCTCCCGT-3'), $\beta$ (5'-CTACTCGGGTATCTAATC-3'), and $\gamma$ (5'-AGGGTTGCGCTCGTTG-3') (C. Sproer, personal communication), amplifying position numbers 29 to 1,492 , inclusive of the M59160 sequence for $S$. marcescens strain ATCC13880, as determined by Woese (45). Each reaction contained $30 \mathrm{ng}$ of DNA, isolated from the organisms as described previously, in a total volume of $25 \mu \mathrm{l}$ containing $3.5 \mathrm{mM} \mathrm{MgCl} 2,0.05 \mathrm{mM}$ each dCTP, dATP, dTTP, and dGTP, $200 \mathrm{pM}$ of each primer, and 1.5 units of Taq polymerase. Amplification was for $95^{\circ} \mathrm{C}$ for $3 \mathrm{~min} ; 35$ cycles of $60 \mathrm{~s}$ at $92^{\circ} \mathrm{C}, 45 \mathrm{~s}$ at $47^{\circ} \mathrm{C}$, and $90 \mathrm{~s}$ at $72^{\circ} \mathrm{C}$; followed by $10 \mathrm{~min}$ at $72^{\circ} \mathrm{C}$.

For analysis, PCR products were electrophoretically separated in $1.5 \%$ MetaPhor agarose (FMC BioProducts, Rockville, MD) containing ethidium bromide at $50 \mu \mathrm{g} / \mathrm{liter}$, and band sizes were estimated by comparison with 1-kb Plus DNA Ladder molecular weight markers (Gibco-BRL, Rockville, MD). The resultant PCR products were excised from the gel and prepared for direct se-

TABLE 1. Bacterial strains characterized by sequence analysis and sources of sequences used in phylogenetic tree generation in this study

\begin{tabular}{|c|c|c|c|c|}
\hline \multirow[b]{2}{*}{ Bacterial identity } & \multirow[b]{2}{*}{ Strain } & \multirow[b]{2}{*}{ Source $^{b}$} & \multicolumn{2}{|c|}{ GenBank accession number ${ }^{\mathrm{a}}$} \\
\hline & & & $16 \mathrm{~S}$ rDNA & GroE \\
\hline \multicolumn{5}{|l|}{ Serratia spp. used } \\
\hline S. marcescens & W01-A & CYVD watermelon (Texas) & AJ296309 & AJ297252 \\
\hline S. marcescens & Z01-A & CYVD zucchini squash (Oklahoma) & AJ296310 & AJ297253 \\
\hline S. marcescens & $90-166^{c}$ & Cotton root (Alabama) & AJ296306 & AJ297249 \\
\hline S. marcescens & $98 \mathrm{~A}-742^{\mathrm{c}}$ & Soil treated with DiTera (Florida) & AJ296307 & AJ297250 \\
\hline S. marcescens & $\mathrm{CP} 01(4) \mathrm{CU}^{\mathrm{c}}$ & Rhizosphere, golf course (Florida) & AJ296308 & AJ297251 \\
\hline S. marcescens & $\mathrm{JM}-965^{\mathrm{c}}$ & Cotton stems (Florida) & AJ302154 & AJ302157 \\
\hline S. plymuthica & $\mathrm{JM}-983^{\mathrm{c}}$ & Cotton roots (Florida) & AJ302155 & AJ302158 \\
\hline S. marcescens & $\mathrm{HO} 1-\mathrm{A}^{\mathrm{d}}$ & Human, clinical (Oklahoma) & AJ297946 & AJ297956 \\
\hline S. marcescens & $\mathrm{H} 02-\mathrm{A}^{\mathrm{d}}$ & Human, clinical (Oklahoma) & AJ297950 & AJ297957 \\
\hline Serratia sp. & IRBG $501^{\mathrm{e}}$ & Rice (Philippines) & AJ302156 & AJ302159 \\
\hline \multicolumn{5}{|l|}{ Serratia sequences ${ }^{\mathrm{f}}$} \\
\hline S. marcescens & JCM 1239 & $\ldots$ & $\ldots$ & $\mathrm{AB} 008145$ \\
\hline S. marcescens & DSM 30121 & $\ldots$ & AJ233431 & $\ldots$ \\
\hline S. rubidaea & JCM 1240 & $\ldots$ & $\ldots$ & $\mathrm{AB} 008143$ \\
\hline S. rubidaea & DSM 4480 & $\ldots$ & AJ233436 & $\ldots$ \\
\hline S. ficaria & JCM 1241 & $\ldots$ & $\ldots$ & $\mathrm{AB} 008144$ \\
\hline S. ficaria & DSM 4569 & $\ldots$ & AJ233428 & $\ldots$ \\
\hline \multicolumn{5}{|l|}{ Non-Serratia sequences ${ }^{\mathrm{f}}$} \\
\hline Enterobacter asburiae & JCM 6051 & $\ldots$ & $\mathrm{AB} 004744$ & AB008137 \\
\hline Klebsiella planticola & JCM 7251 & $\ldots$ & $\ldots$ & $\mathrm{AB} 008148$ \\
\hline K. planticola & ATCC $33531 \mathrm{~T}$ & $\ldots$ & X93216 & $\ldots$ \\
\hline Erwinia carotovora & IAM 12633 & $\ldots$ & $\ldots$ & $\mathrm{AB} 008152$ \\
\hline E. carotovora & DSM 30168 & $\ldots$ & Z96090 & $\ldots$ \\
\hline Sitophilus oryzae endophyte & $\ldots$ & $\ldots$ & AF005235 & AF005236 \\
\hline
\end{tabular}

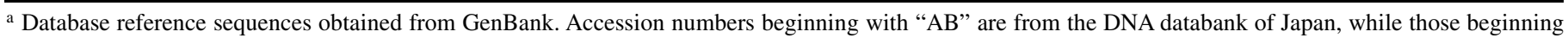
with "AJ" are from the EMBL sequence database.

${ }^{\mathrm{b}} \mathrm{CYVD}=$ cucurbit yellow vine disease.

c Provided by J. Kloepper, University of Alabama, Auburn, AL; who identified the bacteria by fatty acid methyl ester analysis.

${ }^{\mathrm{d}}$ Provided by D. Adamson, Medical Arts Laboratory, Oklahoma City, OK; who identified the bacteria by substrate utilization using API 20E.

e Provided by J. K. Ladha, International Rice Research Institute, Los Baños, Philippines; who identified the bacteria by 16S rDNA sequencing (16).

${ }^{\mathrm{f}}$ Sequences from databases used as reference sequences in this study. 
quencing using a QIAquick gel extraction kit (Qiagen Inc., Valencia, CA). The gel-purified DNAs were quantified by electrophoresis and compared with herring sperm DNA of known quantity. Automated sequencing was performed by the Oklahoma State University Recombinant DNA/Protein Resource Facility, using dye-terminated thermal cycle sequencing and an Applied Biosystems/Perkin-Elmer 373 sequencer (Perkin-Elmer Inc., Wellesley, MA).

Sequence editing and phylogenetic tree construction. Resulting sequences were aligned and edited using BioEdit software (version 4.7.3; T. Hall, North Carolina State University). Phylogenetic trees based on groE and $16 \mathrm{~S}$ rDNA sequences were compiled using PHYLIP programs (13). The 16S rDNA and groE sequences of six other plant- or insect-related members of the family Enterobacteriaceae were obtained from GenBank (Table 1). Distance matrices were calculated with DNADIST and used to construct trees by neighbor joining as implemented in NEIGHBOR. The phylogenetic trees were displayed using TreeView (29). Alignments were bootstrapped 1,000 times using SEQBOOT, and bootstrap values were added to the internal branches of the distance trees. Branches with bootstrap values less than 500 were collapsed.

Fatty acid and substrate utilization tests. Triply cloned cultures of each bacterium were streaked onto purple agar (Difco Laboratories, Detroit), grown at $28^{\circ} \mathrm{C}$, and provided to $\mathrm{E}$. Dickstein, University of Florida, Gainesville, for analyses of fatty acid methyl ester (FAME; MIDI, Inc., Newark, DE) and substrate utilization (BIOLOG, Inc., Hayward, CA) profiles, which were performed following manufacturers' instructions. The BIOLOG tests were done using substrate plates designed for gram-negative bacteria. FAME testing was repeated a total of three times, and BIOLOG twice. The Vitek and API 20E (BioMérieux, Hazlewood, MO) automated bacterial identification assays, which included substrate utilization and antibiotic sensitivity tests and were analyzed by comparisons with a database composed of medically important strains, were performed once each by D. Adamson, Medical Arts Laboratories, Oklahoma City, OK, following manufacturers' instructions.

\section{RESULTS}

Preliminary characterization. When streaked onto agar-solidified LB medium, cucurbit-derived bacterial strains all produced smooth, circular, entire, convex, nonpigmented colonies within $24 \mathrm{~h}$. All the tested bacterial strains were gram negative, as indicated by the formation of dense, slimy threads when loopfuls of bacteria were stirred into $\mathrm{KOH}$ solution. After being stabbed into O-F medium, all strains grew and produced acidic byproducts, as indicated by a color change in the acid-base indicator, whether covered or not covered with sterile Vaseline (Table 2). These data demonstrate that all of the tested strains are facultative anaerobes.

Nucleic acid sequencing. Approximately $1.3 \mathrm{~kb}$ of $\operatorname{groE}$ (a fragment containing approximately $80 \%$ of the groES gene and $60 \%$ of the groEL gene) and $1.4 \mathrm{~kb}$ of $16 \mathrm{~S}$ rDNA (approximately $91 \%$ of the gene) homologues were sequenced for the two CYVD and eight reference strains. Sequences were subjected to multiple sequence alignments. To obtain reliable alignments for the groE sequences, the intergenic region between groES and groEL was excluded. The groE sequences of the two CYVD strains and six of the other eight strains were highly similar to each other, as reflected in pairwise distance values averaging $0.01 \pm 0.005 \mathrm{nu}-$ cleotide substitutions per site for the sequences from these eight strains (two CYVD and six others). In contrast, the groE sequences of the remaining two reference strains, JM-965 and JM983 , both of which are endophytes of cotton, were significantly more distant from the cluster of eight and from each other, with mean distances of $0.10 \pm 0.005$ for JM-965 and $0.045 \pm 0.004$ for
JM-983. For $16 \mathrm{~S}$ rDNA sequences, the mean pairwise distance was $0.002 \pm 0.0012$ within the eight closely related strains, a value five times lower than that obtained for the $g r o E$ set. For the two more distantly related strains, JM-965 and JM-983, values were $0.023 \pm 0.0009$ and $0.034 \pm 0.0125$, respectively.

Phylogenetic tree development. Parsimony analysis of both sequence sets failed to produce phylogenetic trees with reliable branches, due to the small number of phylogenetically informative positions in the data sets. Positions with substitutions in only one lineage contribute to phylogenetic distance; therefore, distances (number of substitutions per site) between all pairs of sequences in each set were calculated by DNADIST.

Phylogenetic trees were generated from the distance data using the PHYLIP program NEIGHBOR (Figs. 1 and 2). Homologous sequences from other known members of the family Enterobacteriaceae having plant or insect associations were included in the phylogenetic analysis for comparison (Table 1). The bacterial symbiont of Sitophilus oryzae, an enterobacterium closely related to Serratia spp. for which both $16 \mathrm{~S}$ rDNA and groE sequences were available, was chosen as the outgroup. For $16 \mathrm{~S}$ rDNA data,

TABLE 2. Partial substrate utilization profiles of the cucurbit bacterial strains W01-A and Z01-A, the cotton endophyte Serratia marcescens 90166 , the clinical strain $S$. marcescens H02-A, and a reference strain of $S$. marcescens $^{\mathrm{a}}$

\begin{tabular}{|c|c|c|c|c|c|}
\hline Test & W01-A & Z01-A & $90-166$ & H02-A & $S m^{\mathrm{b}}$ \\
\hline \multicolumn{6}{|l|}{ BIOLOG } \\
\hline$\alpha$-D-Lactose & 0 & 0 & 0 & + & + \\
\hline$\alpha$-Hydroxybutyric acid & 0 & 0 & \pm & + & + \\
\hline$\alpha$-Ketoglutaric acid & \pm & 0 & + & + & + \\
\hline$\beta$-Hydroxybutyrate & 0 & 0 & + & + & + \\
\hline Adonitol & 0 & 0 & + & + & + \\
\hline Alaninamide & 0 & 0 & + & + & + \\
\hline Bromosuccinic acid & \pm & 0 & + & + & + \\
\hline Cellobiose & 0 & 0 & \pm & + & \pm \\
\hline DL-Lactic acid & 0 & 0 & + & + & + \\
\hline D-Alanine & 0 & 0 & + & + & + \\
\hline D-Arabitol & 0 & 0 & + & + & + \\
\hline D-Mellobiose & \pm & 0 & + & + & + \\
\hline D-Serine & 0 & 0 & + & + & + \\
\hline D-Sorbitol & \pm & 0 & \pm & + & + \\
\hline Gentobiose & 0 & 0 & + & + & + \\
\hline Glucuronamide & \pm & 0 & + & + & + \\
\hline Hydroxy-L-proline & 0 & 0 & + & + & + \\
\hline$i$-Erythritol & 0 & 0 & + & + & \pm \\
\hline L-Alanine & 0 & 0 & + & + & + \\
\hline L-Ananyl glycine & 0 & 0 & + & + & + \\
\hline L-Arabinose & 0 & 0 & + & + & + \\
\hline L-Aspartic acid & 0 & 0 & + & + & + \\
\hline L-Fucose & 0 & 0 & + & + & + \\
\hline L-Ornithine & 0 & 0 & \pm & + & + \\
\hline L-Phenylalanine & 0 & 0 & \pm & \pm & + \\
\hline$m$-Inositol & 0 & 0 & + & + & + \\
\hline$N$-Acetyl-D-galactosamine & 0 & 0 & + & + & + \\
\hline Putrescine & 0 & 0 & + & + & + \\
\hline Succinamic acid & \pm & 0 & + & \pm & \pm \\
\hline Thymidine & 0 & 0 & + & + & + \\
\hline \multicolumn{6}{|l|}{ Vitek } \\
\hline Adonitol fermentation & 0 & 0 & + & ND & + \\
\hline Coumarin & 0 & 0 & + & ND & + \\
\hline Esculin hydrolysis & + & + & 0 & ND & \pm \\
\hline Inositol fermentation & 0 & 0 & + & ND & + \\
\hline Lysine & 0 & 0 & + & ND & + \\
\hline Maltose fermentation & 0 & 0 & + & ND & 0 \\
\hline Ornithine & 0 & 0 & + & ND & + \\
\hline
\end{tabular}

a BIOLOG and Vitek data are presented only for the reactions in which cucurbit yellow vine disease (CYVD) strains differed unequivocally from those of reference strains. For example, in BIOLOG, utilization profiles of the CYVD strains were indistinguishable from those of reference strains for 65 of the 95 substrates. Symbols: $0=$ no activity, $+=$ activity; $\pm=$ questionable, and ND = not done.

b BIOLOG and Vitek database information for a reference strain of $S$. marcescens is included for comparison; these strains were not tested in our assays. 
branching patterns varied considerably, depending on which distantly related sequence was included as outgroup and on which other members of Enterobacteriaceae were included in the data set. However, the relative $16 \mathrm{~S}$-based placement of the bacteria used in our study remained consistent despite these variables, and clearly identified the CYVD strains as $S$. marcescens.

The $g r o E$-based phylogenetic tree also placed the two cucurbit bacterial strains among known strains of $S$. marcescens. In contrast to the low reliability of the $16 \mathrm{~S}$ rDNA trees, branching patterns generated for species within the family Enterobacteriaceae using groE data were similar to each other. Because of this consistency, the confidence level associated with phylogenetic relationship prediction using the groE sequence data is higher than that using the $16 \mathrm{~S}$ rDNA data. In addition, the correspondingly high bootstrap values result in significant branch points in the $g r o E$-based phylogenetic tree that are not present in the $16 \mathrm{~S}$ tree. Harada et al. (18), who characterized a number of members of the family Enterobacteriaceae on the basis of their groE sequences, omitted the spacer region between the groES and groEL genes to obtain a reliable alignment for phylogenetic comparison. In our study, including or deleting this spacer region made no difference in the resulting phylogenetic trees, even though there were clear base differences in this segment.

In addition to placing the CYVD strains W01-A and Z01-A close to known $S$. marcescens strains DSM 30121 and JCM 1239, both the 16S-based and the groE-based trees show their close relationship to the human clinical strains H01-A and H02-A. Also included in this closely related grouping are soil strains CP01(4)CU and 98A-742, and plant endophytes 90-166 (cotton) and IRBG 501 (rice).

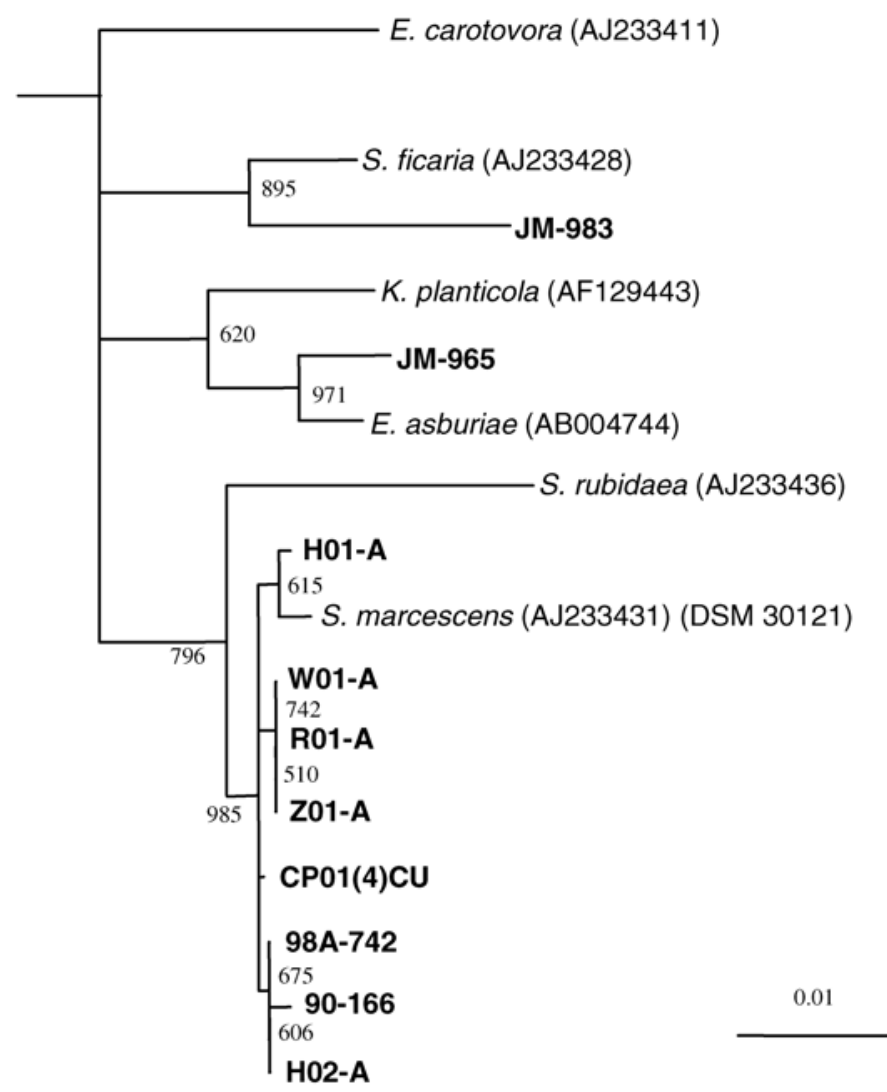

Fig. 1. Phylogenetic distance tree compiled from 16S rDNA sequence data using programs DNADIST and NEIGHBOR, with the endosymbiont of Sitophilus oryzae as outgroup. Branches with bootstrap values less than 500 were collapsed, and two branches (bootstrap values 510 and 606) were of relative lengths insufficient for resolution at the scale of this figure. Strains indicated in bold font were used in this study; the remainder are database reference strains. RO1-A is the rice strain IRBG 501.
As mentioned previously, strains JM-983 and JM-965, isolated from cotton roots and stems, respectively, were outside the $S$. marcescens cluster. A BLASTn search initiated with the groE sequence from JM-983 yielded $S$. marcescens JCM 1239 as the best fit, with 1,239 of 1,292 nucleotides (nt) identical. BLASTn analysis of the $16 \mathrm{~S}$ rDNA sequence identified $S$. grimesii DSM 30063 as the most similar to this strain, with 1,402 of $1,406 \mathrm{nt}$ identical. $S$. grimesii was not included in our phylogenetic trees because groE sequence data was unavailable for this organism. Of all the strains compared, JM-965, a cotton stem endophyte, is the least related to the others. Here again, gro $\mathrm{E}$ and $16 \mathrm{~S}$ sequence database searches yielded somewhat different results; Enterobacter asburiae JCM 6051 was the species having greatest similarity to the JM-965 groE sequence by BLASTn search $(1,233$ of $1,282 \mathrm{nt})$, whereas E. cloacae (1,402 of 1,406 nt) was the most similar 16S rDNA sequence available in the databases.

Fatty acid analysis. Although comparisons of CYVD bacterial fatty acid profiles with those of known bacteria in the MIDI database revealed "closest match" genera and species, the similarity indices of these matches were very low. However, all of the closest match species were in the family Enterobacteriaceae, and the cucurbit strains possessed a 14:0 3-hydroxy fatty acid that is characteristic of this bacterial family.

The MIDI program (12) was used to generate a principle component analysis comparing the fatty acid makeup of the CYVD bacterial strains with those of specific reference and database strains of Serratia spp. The two cucurbit strains, W01-A and Z01A, clustered together, well separated from all known database Serratia spp. (Fig. 3). They also clearly were different from two strains, H02-A and 90-166, used as references in the current study. The relationship between any two strains was estimated by multiplying the difference between their $x$-axis positions by the distance between their $y$-axis positions. MIDI instructions suggest that values of $\geq 110$ are indicative of separate species, while values of $<60$ suggest that two strains are in the same subspecies. Bacteria having values of $<30$ are recommended for assignment to the same strain.

In this analysis, the only within-species comparison of established strains is that of $S$. marcescens A versus $S$. marcescens B (the two groups of database $S$. marcescens, distinguishable from one another by their fatty acid profiles), which yielded a value of 6.2. To create a larger comparison group, the two analyses of the known human strain, H02-A, were added to those of $S$. marcescens $\mathrm{A}$ and $\mathrm{B}$, yielding a range of scores from 4.2 to 7.8. Among all the between-species comparisons, six were in or below this range: $S$. rubidaea versus $S$. marcescens A, $S$. rubidaea versus $S$. marcescens B, S. rubidaea versus $S$. odorifera; $S$. odorifera versus S. fonticola, $S$. odorifera versus $S$. grimesii; and $S$. liquifaciens versus $S$. marcescens B. Five of the six involved $S$. rubidaea and $S$. odorifera, suggesting that these bacteria may be very similar. The bulk of the comparisons between species acknowledged to be different yielded values from 11.0 to 168 . These values are, on average, considerably less than the MIDI standard of $\geq 110$.

Clearly, the general MIDI standards are inadequate for Serratia spp., although the reason is not clear. Substituting the withinspecies MIDI range of 4.2 to 7.8, and between-species range of 11 to 168 (derived from the data for established species), W01-A and Z01-A were placed in the same species as S. fonticola, S. plymuthica, S. odorifera (except one of the three Z01-A replications), and 90-166B. This approach clearly separated the two cucurbit strains from $S$. marcescens A and B, S. marcescens H01-A, S. rubidaea, S. liquifaciens, $S$. grimesii, $S$. odorifera (one of the three Z01-A replications only), and 90-166A.

Substrate utilization and other biological features. Analyses based entirely (BIOLOG) or predominantly (Vitek and API 20E) on substrate utilization profiles revealed indistinguishable reaction patterns for the two CYVD strains, and showed that they were unequivocally distinct in these tests from the eight test reference 
strains and from all known Serratia strains in the corresponding databases. For example, although W01-A and Z01-A had the same utilization reactions as the reference $S$. marcescens for 65 of the 95 substrates on the Biolog plates, they differed in their ability to metabolize the other 30 substrates (Table 2). Interestingly, in all but one case (esculin hydrolysis), the differences in BIOLOG substrate utilization reflected a lack, in the cucurbit strains, of functions present in the $S$. marcescens reference strains. Although BIOLOG data showed that CYVD strain W01-A had the highest similarity to Aeromonas veronii and that Z01-A had the highest similarity to Vibrio cholerae, the similarity rankings (30 and $40 \%$, respectively) were too low to be considered reliable. In the Vitek analysis, the reaction profiles of the CYVD strains were so dissimilar from those of the databank species that the automated system found no species matches. In addition, DNAse activity, often considered diagnostic for $S$. marcescens (20), was not detected in the cucurbit strains (API-20, data not shown). In contrast to the somewhat contradictory results for strains W01-A and Z01-A, the endophytic reference strain, 90-166, was clearly identified as $S$. marcescens by both BIOLOG (91\% similarity) and Vitek (99\% similarity).

\section{DISCUSSION}

CYVD, a disease of significant economic importance in several regions of the United States, is caused by a cultivable, gram-negative, facultatively anaerobic phloem-resident bacterium. Preliminary sequence comparisons of $16 \mathrm{~S}$ rDNA PCR amplified directly from infected plant tissue (3) suggested that it was a $\gamma$-proteobacterium in the family Enterobacteriaceae, related to Serratia spp. In the work reported here, rigorous analysis of sequences from both $16 \mathrm{~S}$ rDNA and groE genomic regions of cultivated and triply cloned bacterial strains demonstrated that the CYVD bacterium is $S$. marcescens. The phylogenetic relationships among $S$. marcescens and other members of Enterobacteriaceae have been well documented $(19,37,45)$.

The identity of the pathogen was unexpected because $S$. marcescens is not typically associated with plant disease and had not been known previously to colonize plant phloem. Capable of thriving in diverse habitats and ecological niches, $S$. marcescens has been isolated from soil, water, plants, food products, and in-

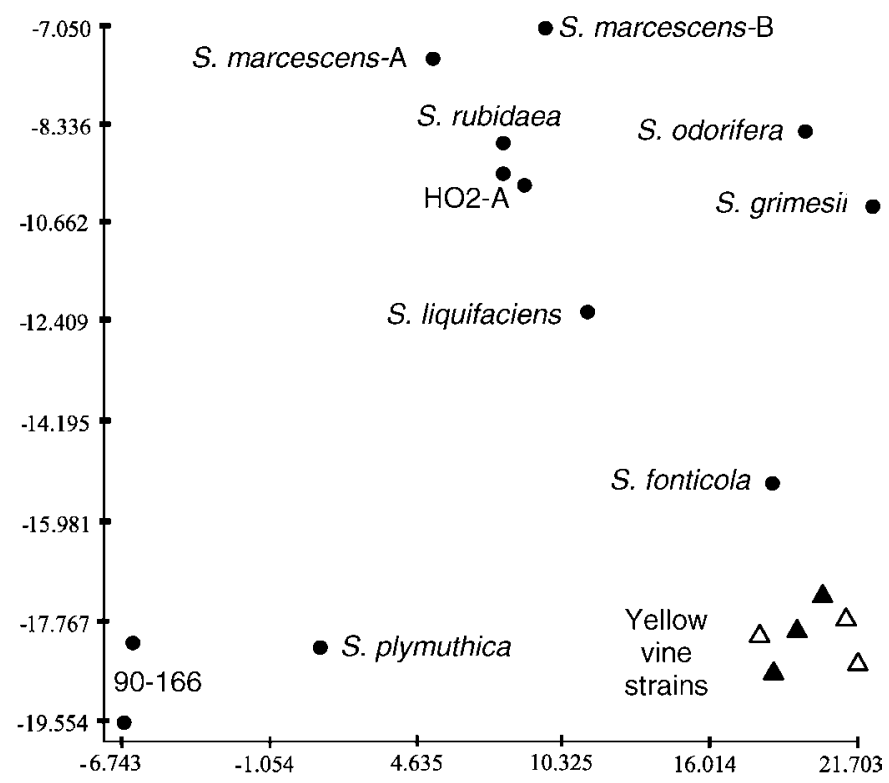

Fig. 3. Principle component analysis of fatty acid methyl ester profile data for cucurbit strains W01-A (black triangles) and Z01-A (white triangles), the human strain Serratia marcescens H02-A, the endophyte S. marcescens 90166, and several Serratia reference strains.

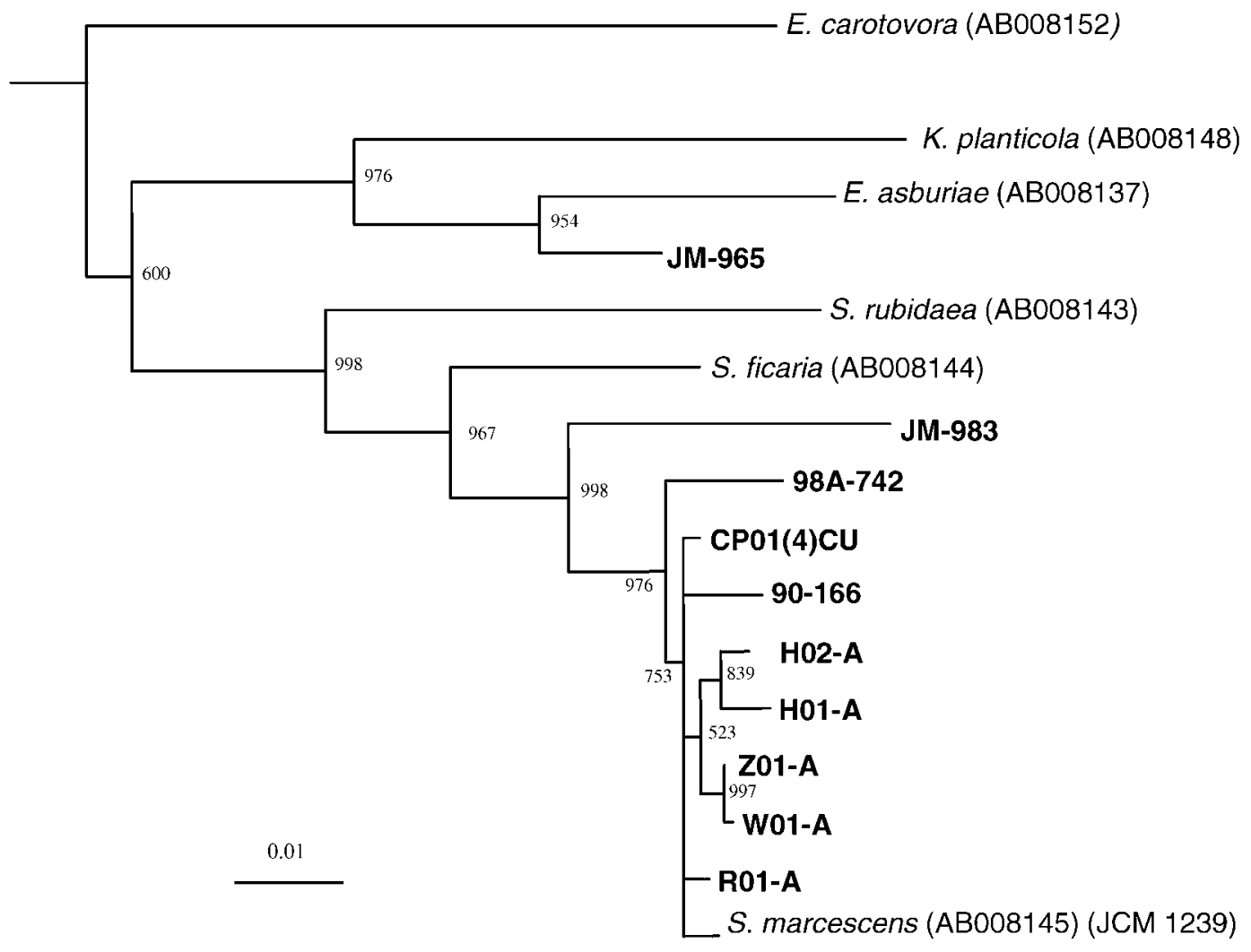

Fig. 2. Phylogenetic distance tree compiled from groE sequence data, using programs DNADIST and NEIGHBOR, with the endosymbiont of Sitophilus oryzae as outgroup. Branches with bootstrap values less than 500 were collapsed. Strains indicated in bold font were used in this study; the remainder are database reference strains. RO1-A is the rice strain IRBG 501. 
fections of animals, including insects and humans (1,16,22,33, $36,38)$. Various plant-associated roles are filled by this species, including that of a plant-growth-promoting rhizobacterium (24, 25); an innocuous colonizer or endophyte of plants, including cotton and rice $(39,41)$; and even a biocontrol agent capable of reducing or preventing infections by bacterial or fungal pathogens $(25,46)$. Previous to this study, $S$. marcescens had been implicated as a plant pathogen in only two cases: crown rots of the grain legumes sainfoin (34) and alfalfa $(26,40)$. In both of the latter cases, $S$. marcescens was thought to be part of a pathogen complex, and bacterial species identification was determined without access to current molecular bacterial identification procedures. The fact that $S$. marcescens is also a pathogen of many insect species $(14,23,35)$ suggests the possibility that the interactions between the CYVD bacterium and an insect vector, such as $A$. tristis, may involve more than a simple contamination of legs or mouthparts. In addition, the fact that at least some strains of $S$. marcescens can be opportunistic pathogens of immunocompromised humans prompts interest in the question of whether the CYVD strains differ in this respect from strains derived from other niches.

Phylogenetic trees generated independently from 16S rDNA and groE sequences both show that the two CYVD strains of $S$. marcescens, W01-A and Z01-A, are almost identical to each other. In addition, their branch placement clearly suggests their close relationship to human clinical strains, soil strains, and plant endophytes. However, the CYVD bacteria differ significantly from other strains of $S$. marcescens based on automated substrate utilization assays and fatty acid analysis. The biologically or functionbased tests BIOLOG, Vitek, API-20E, and FAME indicate that the metabolic capabilities and fatty acid composition of these cucurbit strains are quite different from those of the type strain of $S$. marcescens as well as from several other reference strains.

In all but one of the cases in which the CYVD strains differed from other strains of $S$. marcescens in the BIOLOG analysis, W01-A and Z01-A were unable to utilize substrates metabolized by the known strains. This interesting observation may reflect niche specificity, the adaptation of the cucurbit strains to a parasitic and pathogenic role within the host plant, in which they no longer require all the proteins or enzyme pathways normally expressed in S. marcescens. Interestingly, in fellow Enterobacteriaceae member Escherichia coli, a span of approximately $130 \mathrm{kbp}$, starting with the $16 \mathrm{~S} r r n$ gene and ending at the termination of the groE gene (a region covering approximately $1 / 40$ of the chromosome), contains at least 10 genes that may be involved in some of the metabolic functions tested in BIOLOG and Vitek and found missing in the CYVD strains: glutamate-aspartate symport protein, putative amino acid/amine transport protein, regulator of melibiose operon, $\alpha$-galactosidase, melibiose permease II, anaerobic dicarboxylate transport, lysine decarboxylase 1, lysine/ cadaverine transport, anaerobic dicarboxylate transport, and aspartate ammonia-lyase (aspartase). If these genes are grouped similarly in $S$. marcescens (a scenario that is not necessarily expected), they could have been lost in a single event.

The fact that known $S$. marcescens strains and those from CYVD-affected plants strongly resemble one another by $16 \mathrm{~S}$ rDNA and groE sequence data, but differ significantly in their metabolic profiles, prompts the question of whether the CYVD bacteria could belong to a different taxonomic group that serendipitously acquired both $16 \mathrm{~S}$ rDNA and groE gene sequences by some mechanism of transformation from $S$. marcescens. However, although $S$. marcescens probably has multiple ribosomal operons (Enterobacteriaceae member E. coli has seven) (11), our $16 \mathrm{~S}$ sequence analysis showed no evidence of heterogeneity among putative copies, suggesting that all must be virtually identical. Thus, if one copy had been acquired by transformation from another bacterial species, then all must have been so, an unlikely scenario. To settle this question definitively, entire genome comparisons of numerous strains of CYVD bacteria and known reference strains were performed by repetitive elements-based PCR and by DNADNA hybridization analysis; results of those investigations are reported in Zhang et al. (47).

Our findings are similar to those from a recent analysis by $16 \mathrm{~S}$ rDNA sequencing and DNA-DNA hybridizations of six endophytic bacterial strains isolated from rice roots and stems in the Philippines $(17,39)$. The rice strains were closely related to one another (93\% similarity in cluster analysis) and to S. marcescens (all within an $86 \%$ similarity level). However, as with the CYVD strains, the rice strains differed from the type strain in several key nutrient utilization characteristics, leading the authors to conclude that the rice endophytes represent a novel group of nonpigmented S. marcescens.

It is not surprising that long-term association with a particular niche would result in the retention of niche-supportive traits and possible loss of nonessential genes. Signal sensing or regulatory mechanisms operating in the CYVD strains may be responsible for the absence of certain gene products even if the bacteria possess the relevant functional genes. Alternatively, reductive evolution in intracellular bacteria, which may no longer require metabolic functions necessary for a free-living existence, often has led to reduced genome sizes (44). Determination of the genome size of the CYVD strains of $S$. marcescens, work ongoing at this time, will provide insight into possible genome losses.

The wide range of roles played by $S$. marcescens include those of epiphytes, endophytes, soil inhabitants, insect pathogens, and nosocomial human pathogens $(1,7,14,16,33,36,38)$. Our knowledge of the abilities of particular strains of $S$. marcescens to occupy multiple niches, such as being pathogenic to both plants and humans, is only rudimentary. However, the differences in substrate utilization patterns and fatty acid profiles between cucurbit-derived strains of this bacterium and other strains of the species would suggest that substantial changes in gene content or expression, or both, have occurred during the process of this bacterium's adaptation to life in plant sieve tubes.

\section{ACKNOWLEDGMENTS}

The work was funded by the Oklahoma Agricultural Experiment Station Project 2052 and the USDA Southern Regional IPM Grants Program. We thank E. Dickstein, University of Florida (BIOLOG and FAME), D. Adamson, Medical Arts Laboratories, Oklahoma City, OK (Vitek and API), and L. Kong (KOH and O-F tests) for assay assistance; J. Loper and C. Press (Oregon State University), J. Kloepper (Auburn University), J. K. Ladha (International Rice Research Institute, Los Baños, Philippines), and D. Adamson for providing bacterial strains used in the study; M. Vijayakumar and C. Bender (Oklahoma State University), and S. E. Katz (Midwestern University, Glendale, AZ) for excellent presubmission manuscript reviews; and the Oklahoma State University Recombinant DNA/Protein Resource Facility for synthesizing PCR primers and doing the automated sequencing.

\section{LITERATURE CITED}

1. Ahrenholtz, I., Lorenz, M. G., and Wackernagel, W. 1994. The extracellular nuclease of Serratia marcescens: Studies on the activity in vitro and effect on transforming DNA in a groundwater aquifer microcosm. Arch. Microbiol. 161:176-183.

2. Ausubel, F. M., Brent, R., Kingston, R. E., Moore, D. M., Seidman, J. G., Smith, J. A., and Struhl, K. (eds.) 1987. Short Protocols in Molecular Biology. John Wiley \& Sons, New York.

3. Avila, F. J., Bruton, B. D., Fletcher, J., Sherwood, J. L., Pair, S. D., and Melcher, U. 1998. Polymerase chain reaction detection and phylogenetic characterization of an agent associated with yellow vine disease of cucurbits. Phytopathology 88:428-436.

4. Bextine, B. E. 2001. Insect transmission of Serratia marcescens, the causal agent of cucurbit yellow vine disease. Ph.D. thesis. Oklahoma State University, Stillwater.

5. Bextine, B., Wayadande, A., Pair, S., Bruton, B., Mitchell, F., and Fletcher, J. 2001. Parameters of Serratia marcescens transmission by the squash bug, Anasa tristis. (Abstr.) Phytopathology 91(suppl.):S8. 
6. Bost, S. C., Mitchell, F. L., Melcher, U., Pair, S. D., Fletcher, J., Wayadande, A., and Bruton, B. 1999. Yellow vine of watermelon and pumpkin in Tennessee. Plant Dis. 83:587.

7. Bruton, B., Brady, J. Mitchell, F., Bextine, B., Wayadande, A., Pair, S., Fletcher, J., and Melcher, U. 2001. Yellow vine of cucurbits: Pathogenicity of Serratia marcescens and transmission by Anasa tristis. (Abstr.) Phytopathology 91(suppl.):S11.

8. Bruton, B. D., Fletcher, J., Pair, S. D., Shaw, M., and Sittertz-Bhatkar, H. 1998. Association of phloem-limited bacteria with yellow vine disease in cucurbits. Plant Dis. 82:512-520.

9. Bruton, B. D., Mitchell, F., Fletcher, J., Pair, S. D., Wayadande, A., Melcher, U., Brady, J., Bextine, B., and Popham, T. W. 2003. Serratia marcescens, a phloem-colonizing, squash bug-transmitted bacterium: Causal agent of cucurbit yellow vine disease. Plant Dis. 87:937-944.

10. Bruton, B. D., Pair, S. D., Popham, T. W., and Cartwright, B. O. 1995. Occurrence of yellow vine, a new disease of squash and pumpkin, in relation to insect pests, mulches, and soil fumigation. Subtrop. Plant Sci. 4:53-58.

11. Cole, S. T., and Saint-Girons, I. 1999. Bacterial genomes-all shapes and sizes. Pages 35-62 in: Organization of the Prokaryotic Genome. R. L. Charlebois, ed. American Society for Microbiology, Washington, D.C.

12. Dickstein, E. R., Jones, J. B., and Stead, D. E. 2001. Automated techniques: Physiological and biochemical methods; fatty acid analysis. Pages 343-345 in: Laboratory Guide for Identification of Plant Pathogenic Bacteria. 3rd ed. N. W. Schaad, J. B. Jones, and W. Chun, eds. The American Phytopathological Society, St. Paul, MN.

13. Felsenstein, J. 1989. Phylogeny inference package. Cladistics 5:164-166.

14. Flyg, C., Kenne, K., and Boman, H. G. 1980. Insect pathogenic properties of Serratia marcescens: Phage resistant mutants with a decreased resistance to Cecropia immunity and a decreased virulence to Drosophila. J. Gen. Microbiol. 120:173-181.

15. Govan, J. R. W., Balendreau, J., and Vandamme, P. 2000. Burkholderia cepacia-friend and foe. ASM News 66:124-125.

16. Grimont, P. A. D., and Grimont, F. 1992. The genus Serratia. Pages 2822-2848 in: The Prokaryotes: A Handbook on Habitats, Isolation, and Identification of Bacteria. Springer-Verlag, New York.

17. Gyaneshwar, P., James, E. K., Mathan, N., Reddy, P. M., ReinholdHurek, B., and Ladha, J. K. 2001. Endophytic colonization of rice by a diazotrophic strain of Serratia marcescens. J. Bacteriol. 183:2634-2645.

18. Harada, H., and Ishikawa, H. 1997. Phylogenetical relationship based on groE genes among phenotypically related Enterobacter, Pantoea, Klebsiella, Serratia and Erwinia species. J. Gen. Appl. Microbiol. 43:355-361.

19. Hauben, L., Moore, E. R. B., Bauterin, L., Steenackers, M., Mergaert, J., Verdonck, L., and Swings, J. 1998. Phylogenetic position of phytopathogens within the Enterobacteriaceae. System. Appl. Microbiol. 21:384-397.

20. Hejazi, A., and Falkiner, F. R. 1997. Serratia marcescens. J. Med. Microbiol. 46:903-912.

21. Kolbert, C. P., and Persing, D. H. 1999. Ribosomal DNA sequencing as a tool for identification of bacterial pathogens. Curr. Opin. Microbiol. 2:299-305.

22. Kurz, C. L., and Ewbank, J. J. 2000. Caenorhabditis elegans for the study of host-pathogen interactions. Trends Microbiol. 8:142-144.

23. La Scola, B., Fournier, P.-E., Brouqui, P., and Raoult, D. 2001. Detection and culture of Bartonella quintana, Serratia marcescens and Acetinobacter spp. from decontaminated body lice. J. Clin. Microbiol. 39:1707-1709.

24. Liu, L., Kloepper, J. W., and Tuzun, S. 1995. Induction of systemic resistance in cucumber against bacterial angular leaf spot by plant growthpromoting rhizobacteria. Phytopathology 85:843-847.

25. Liu, L., Kloepper, J. W. and Tuzun, S. 1995. Induction of systemic resistance in cucumber against Fusarium wilt by plant growth-promoting rhizobacteria. Phytopathology 85:695-698.

26. Lukezic, F. L., Hildebrandt, D. C., Schroth, M. N., and Schinde, P. A. 1982. Association of Serratia marcescens with crown rot of alfalfa in Pennsylvania. Phytopathology 72:714-718.
27. Melcher, U., Mitchell, F., Pair, S., Fletcher, J., and Bruton, B. 1999. New primer sets distinguish the cucurbit yellow vine bacterium from an insect endosymbiont. (Abstr.) Phytopathology 89(suppl.):S95.

28. McLennan, N., and Masters, M. 1998. GroE is vital for cell-wall synthesis. Nature 392:139.

29. Page, R. D. M. 1996. TREEVIEW: An application to display phylogenetic trees on personal computers. Comput. Appl. Biosci. 12:357-358.

30. Rascoe, J. E., Berg, M., Melcher, U., and Fletcher, J. 2000. 16S rDNA and groE analysis of Serratia marcescens strains from diverse ecological niches. (Abstr.) Phytopathology 90(suppl.):S63.

31. Sambrook, J., Fritsch, E. F., and Maniatis, T. 1989. Molecular Cloning: A Laboratory Manual. 2nd ed. Cold Spring Harbor Laboratory, Cold Spring Harbor, NY.

32. Schaad, N. W. 2001. Initial identification of common genera. Pages 1-17 in: Laboratory Guide for the Identification of Plant Pathogenic Bacteria. 3rd ed. N. W. Schaad, J. B. Jones, and W. Chun, eds. The American Phytopathological Society, St. Paul, MN.

33. Schalk, J. M., Peterson, J. K., and Hamalle, R. J. 1987. The abdominal flora of the banded cucumber beetle Diabrotica balteata Leconte. J. Agric. Entomol. 4:333-336.

34. Sears, R. G., Ditterline, R. L., and Mathre, D. E. 1975. Crown and root rotting organisms affecting sainfoin (Onobrychis vicifolia) in Montana. Plant Dis. Rep. 59:423-426.

35. Sikorowski, P. P., Lawrence, A. M., and Inglis, G. D. 2001. Effects of Serratia marcescens on rearing of the tobacco budworm (Lepidoptera: Noctuidae). Am. Entomol. 47:51-61.

36. Someya, N., and Kataoka, N. 2000. Biological control of cyclamen soilborne diseases by Serratia marcescens strain B2. Plant Dis. 84:334340.

37. Sproer, C., Mendrock, U., Swiderski, J., Lang, E., and Stackebrandt, E. 1999. The phylogenetic position of Serratia, Buttiauxella and some other genera of the family Enterobacteriaceae. Int. J. Syst. Bacteriol. 49:1433-1438.

38. Strobel, G., Li, J.-Y., Sugawara, F., Koshino, H., Harper, J., and Hess, W. M. 1999. Oocydin A, a chlorinated macrocyclic lactone with potent antioomycete activity from Serratia marcescens. Microbiology 145:35573564 .

39. Tan, Z., Gyaneshwar, P., Ladha, J. K., and Reinhold-Hurek, B. 2001. Novel endophytes of rice form a taxonomically distinct subgroup of Serratia marcescens. Syst. Appl. Microbiol. 24:245-251.

40. Turner, V., and Van Alfen, N. K. 1983. Crown rot of alfalfa in Utah. Phytopathology 73:1333-1337.

41. Wei, G., Kloepper, J. W., and Tuzun, S. 1996. Induced systemic resistance to cucumber diseases and increased plant growth by plant growth promoting rhizobacteria under field conditions. Phytopathology $86: 221-224$.

42. Weisburg, W. G., Barns, S. M., Pelletier, D. A., and Lane, D. J. 1991. 16S ribosomal DNA amplification for phylogenetic study. J. Bacteriol. 173:697-703.

43. Wick, R. L., Lerner, J., Pair, S. D., Fletcher, J., Melcher, U., Mitchell, F., and Bruton, B. D. 2001. Detection of yellow vine disease in squash and pumpkin in Massachusetts. Plant Dis. 85:1031.

44. Wixon, J. 2001. Reductive evolution in bacteria: Buchnera sp., Rickettsia prowazekii and Mycobacterium leprae. Comp. Funct. Genom. 2:44-48.

45. Woese, C. R. 1987. Bacterial evolution. Microbiol. Rev. 51:221-271.

46. Zehnder, G. W., Murphy, J. F., Sikora, E. J., and Kloepper, J. W. 2001. Application of rhizobacteria for induced resistance. Eur. J. Plant Pathol. 107:39-50.

47. Zhang, Q., Weyant, A. G., Steigerwalt, L. A., White, Melcher, U., Bruton, B. D., Pair, S. D., Mitchell, F. L., and Fletcher, J. 2003. Genotyping of Serratia marcescens strains associated with cucurbit yellow vine disease by repetitive elements-based polymerase chain reaction and DNA-DNA hybidization. Phytopathology 93:1240-1246. 